\title{
Visibility Studies in Archaeology: A Review and Case Study
}

\author{
M. W. Lake ${ }^{1}$ \\ University College London \\ Institute of Archaeology \\ 31-34 Gordon Square \\ London WC1H 0PY
}

\author{
P. E. Woodman \\ University of Reading \\ School of Continuing Education \\ London Road \\ Reading RG1 5AQ
}

2003

Postprint of a paper published in Environment and Planning B, Planning and Design 30: 689-70; DOI: 10.1068/b2912; CPion

${ }^{1}$ Corresponding author. Email: mark.lake@ucl.ac.uk 


\begin{abstract}
This paper describes the history and current state of archaeological visibility studies. The first part is a survey of both GIS and non-GIS studies of visibility by archaeologists, which demonstrates how advances in GIS visibility studies have tended to recapitulate, albeit over a compressed timescale, theoretically driven developments in non-GIS studies. The second part presents an example of the kind of methodological development required for the use of GIS to contribute to the agenda set by certain strands of a more humanistic archaeology. An algorithm developed to retrieve various summaries of the inclination at which points on the horizon are visible from a specified viewpoint was applied to 19 recumbent stone circles in the Grampian region of Scotland. The results suggest that these summaries provides a useful tool for 'unpacking' what archaeologists mean when they claim that the topographic setting of certain stone circles creates an 'impression of circularity'.
\end{abstract}




\section{Introduction}

The principle aim of this paper is to describe the history and current state of archaeological visibility studies to a wider audience in geography, planning and allied disciplines. That said, it also introduces ideas and methods which will interest archaeologists already familiar with visibility studies in their own discipline. The paper comprises two parts. The first provides a survey of both GIS and non-GIS studies of visibility by archaeologists. This part focuses on research driven studies, since the analysis of visibility in cultural resource management is generally less developed and has less to offer other disciplines (but see Batchelor 1999 for an example). The survey is organised so as to demonstrate how advances in GIS visibility studies have tended to recapitulate, albeit over a compressed timescale, theoretically driven developments in non-GIS studies. The second part of this paper presents an example of the kind of methodological development required for the use of GIS to contribute to the agenda set by certain strands of a more humanistic archaeology. Specifically, it explores the feasibility of using GIS to measure a subjective property, the impression of circularity, created by the topographic setting of a given location.

\section{Visibility Studies in Archaeology}

Archaeologists' interest in visibility can be traced back considerably further than the ten years or so during which they have begun to explore computer and, in particular, GIS based methods of visibility analysis. The following survey charts the development of non-GIS visibility studies and then shows how GIS studies have followed a similar pathway.

\subsection{Non-GIS Visibility Studies}

A review of non-GIS visibility studies suggests that they fall into three groups: informal studies, statistical studies and humanistic studies.

Informal visibility studies are characterised by the absence of an explicit methodology and the development of common-sense interpretation. The archaeological literature contains many passing references to the visibility from, for example, prehistoric hillforts, Roman signal stations 
and Medieval castle walls, but these do not constitute substantive studies of visibility. More interesting here are those works which are cited by others as in some way contributing to the archaeological study of visibility.

A good example of an informal study is Drewett's (1982, pp.49-50) discussion of the view from different types of prehistoric burial mound in East Sussex. Drewett notes that Neolithic long mounds are situated on false crests which provide good views of the river valleys and Weald, but do not permit the extensive downland views that are possible from slightly further uphill. In contrast, oval mounds are situated at the heads of dry valleys or on river valley edge locations, both of which provide more limited views. As a result he suggests that "the long mounds relate to the primary settlement of the river valleys and the oval mounds represent a secondary filling". To the extent that Drewett provides viewshed maps (presumably determined by eye in the field) this constitutes more than a passing reference to visibility. On the other hand, although the logic of his argument appeals to differences between the views from the mounds and between the mounds and other locations, he does not appear to have engaged in any form of systematic sampling of the background population of views. Similarly, the theoretical premise for his interpretation remains unstated.

Another example of an informal visibility study is Devereux' (1991) study of intervisibility at the Avebury Neolithic monument complex. He suggests that the significance of the 40m high artificial mound, Silbury Hill, lay not in its great size alone, but instead in more subtle features such as the placement of a ledge approximately $5 \mathrm{~m}$ below the summit. Thus Devereux notes that while the mound does not stand proud of the chalk downland ridges that surround it, the ledge-summit segment is visible from various monuments and, in particular, the position of the largest standing stone within the Avebury henge (the so-called Obelisk). Furthermore, at certain times of the year, the existence of a 'double horizon' to the east of Silbury Hill produces a corresponding 'double sunrise', leading Devereux to speculate that the mound may have been intended to "monumentalize [this] event" (ibid., p.898). Intriguing though his observations are, Devereux makes no attempt to buttress them by, for example, attempting to establish whether a double sunrise could be achieved elsewhere in the vicinity, apparently because "this would take a considerable time to ascertain" (ibid.). 
Statistical studies of visibility are distinguished by an explicit concern with quantification and inferential rigour. To that extent they may be considered examples of Processual archaeology, that is, the kind of archaeology that developed as a result of the impact of positivism on the social sciences during the 1950s and 1960s (Gibbon 1989) ${ }^{1}$. The European 'flavour' of Processual archaeology was strongly influenced by the New Geography, whose classic texts Locational Analysis in Human Geography (Haggett 1965) and Models in Geography (Chorley and Haggett 1967) provided the stimulus for Analytical Archaeology (Clarke 1968) and Models in Archaeology (Clarke 1972). This influence is clearly seen in the work of Fraser $(1983 ; 1988)$ on the Neolithic of the Orkney Islands. Fraser carried out a substantial study of the location of settlements and chambered cairns (stone built tombs) with respect to a large number of environmental variables, including visibility. His earlier study (1983, pp.298-303) included a field assessment of the view from each of 76 cairns, in which he recorded how many azimuthal degrees of horizon were distant (exceeded $5 \mathrm{~km}$ ), intermediate (between $5 \mathrm{~km}$ and $500 \mathrm{~m}$ ) or restricted (less than $500 \mathrm{~m})$ in view. The results revealed that cairns were located in places with extensive areas of intermediate visibility, from which he tentatively made the "obvious connection... that the cairn-builders lived on, or used, the land within easy walking distance of the cairn" (p.301) - a suggestion eminently in keeping with Renfrew's (1976) use of Neolithic Orkney as a test case for the elaboration of a social archaeology closely styled on the New geography. Note however, that although Fraser's earlier study is quantitative, it is also - unlike Renfrew's - essentially inductive: thus the visibility classes were "chosen by experiment... to partition the visible horizon into sections which are distinctive from each other and consistently recognisable throughout Orkney" (p.299), rather than derived from an a priori notion of what their relevance might be.

Fraser's later (1988) study of visibility from chambered cairns does adhere to a more overtly deductive inferential framework. It is also one of a number of studies (e.g. Barnatt and Pierpont 1983; Bradley et al. 1993a,b; Ruggles et al. 1991) which, while not always explicitly subscribing to, nevertheless support the prospects for a so-called Cognitive-Processual archaeology. The latter, at least as laid out by Renfrew $(1982 ; 1994)$, seeks to address some of the more cogni-

\footnotetext{
${ }^{1}$ Note, however, that the initial enthusiasm for Hempel's hypothetico-deductive method soon waned as archaeologists struggled to apply it in the context of a historical science.
} 
tive or ideological concerns championed by the various strands of post Positivist archaeology (e.g.Hodder 1986) while, nevertheless, retaining a scientific epistemology. Thus, for example, Roese (Roese 1980, p.648-650) used Chi-Square and t-tests to support his argument that Welsh menhirs (standing stones) were sited to face water. Barnatt and Pierpont (1983, p.101) went one step further and used background sampling to test two alternative hypotheses about the function of stone circles: that they were "extremely accurate astronomical observatories" or alternatively "impressive focal points". By comparing the view from stone circles with that from each intersection of a $100 \mathrm{~m}$ grid placed over the landscape, Barnatt and Pierpont were able to argue that the placement of stone circles at locations with particular visibility characteristics was unlikely to have occured by chance alone. Background sampling was later used by Ruggles et al. (1991) to investigate the astronomical significance of sites on the Scottish island of Mull and also by Bradley in a series of studies (Bradley et al. 1993a,b) designed to add methodological rigour to his earlier (1991) suggestion that prehistoric petroglyphs (rock carvings) in northern Britain were located at important viewpoints.

As is the case in geography, many archaeologists have taken a humanistic turn (see, for example, Hodder 1986 and Shanks and Tilley 1987). The resulting Post-Processual archaeology has produced a number of visibility studies that share the Cognitive-Processual interest in ideology and cognition, but which place greater emphasis on non-discursive knowledge and, perhaps most notably, question conventional scientific reasoning (see papers in Edmonds et al. 1990).

The most influential visibility studies in this genre have probably been those of Tilley and his co-workers. Tilley's (1994) A Phenomenology of Landscape seeks "to develop a framework with which to understand long-term relationships between people and features of the landscape" as mediated by the "symbolics of landscape perception and the role of social memory in the choice of site location" (Tilley 1994, pp.1-2). He rejects the standard approach to the study of human land-use, that is identifying correlations between factors such as relief and soils, as "contemporary myth making" (ibid.) and turns instead to the phenomenological philosophy of Heidegger and Merleau Ponty, especially as it has been applied to space by the humanistic geographers Relph (e.g. 1976) and Tuan (e.g. 1977). Whilst ostensibly about more than visi- 
bility, it is perhaps not surprising that a method intended to suggest past peoples' experiences by assuming similar bodily location and orientation to the landscape should, ultimately, rest largely on the visual sense: whereas prehistoric smells and sounds are long lost, the topographic skeleton which is a substantial determinant of visibility is often little altered. Thus Tilley (1994, pp.196-201) walked the Dorset Cursus, a linear earthwork nearly 10km in length, photographing and describing how parts of it and other monuments come in and out of view. Similarly, he and his co-workers (Bender et al. 1997, p.166) peered through a portable frame erected in the entrances of Bronze Age hut circles in order to "think about ... what the inhabitants would have seen as they moved out of their doors".

Other humanistic visibility studies include Barrett (1994, pp.15-17) and Thomas' (1993, p.42) consideration of the changing field of view as one moves along the prehistoric avenue that leads to the Avebury henge. Both authors ask who might have been able to see what from where and thus show greater interest in power relations and social reproduction than is evident in Tilley's work. Bradley $(1994 ; 1998)$ has also written extensively about the role that prehistoric architecture may have played in shaping human experience, although not from an explicitly phenomenological perspective. Later in this paper we look more closely at his idea that stone circles may have provided a microcosm of the surrounding landscape (Bradley 1998, pp.116-131).

\subsection{GIS Visibility Studies}

As noted earlier, developments in the archaeological application of GIS methods for the study of visibility recapitulate the development of archaeological visibility studies more generally.

Early examples of GIS visibility analysis are rather like the informal non-GIS studies discussed above in that they also employ common-sense interpretation rather than an explicit inferential strategy. For example, Gaffney and Stančič $(1991,1992)$ used GIS to establish that Roman towers on the Adriatic island of Hvar are intervisible and then suggested that the location of these towers may have been determined by the need for intervisibility. While it is possible that this suggestion is correct, the authors make no attempt to support it by, for example, demonstrating that intervisibility is unlikely to have occured by chance alone. The same is 
true of a similar study by Ozawa et al. (1995) of intervisibility between hillforts. Indeed, a similar lack of inferential rigour characterises almost all early GIS visibility studies in archaeology (Aldenderfer 1996). Thus, as Fisher et al. (1997, p.583) observe, Madry and Crumley (1990, pp.375-376) fail to establish that the visibility of Iron Age roads from hillforts is unexpected, while Krist and Brown (1994) do not compare the visibility of caribou migration routes from Paleo-Indian sites with the visibility of such routes from non-site locations.

The first statistical GIS visibility studies in archaeology addressed both Processual and Cognitive-Processual concerns. As an example of the former, Van Leusen (1993, p.120) performed a cluster analysis of the geomorphological properties of Palaeolithc/Mesolithic site viewsheds on the grounds that these would be expected to vary for sites that fulfilled different functions within the subsistence system. In contrast, in a more Cognitive-Processual vein, Ruggles et al. (1993, p.127) proposed (but did not initially implement) the use of binary multiple viewshed maps to answer an archaeoastronomical question about the placing of Bronze Age stone rows. More recent statistical visibility studies have almost exclusively addressed cognitive concerns. The European origin of most of these studies explains their focus on cognition, since the idealist leanings of many European GIS practitioners are supported by a relatively widespread belief that visibility provides a route to past cognition. This situation contrasts - but is not necessarily incompatible - with the relative lack of interest in visibility among North American researchers, who typically adopt a more functionalist stance. Examples of this cognitive genre include the work of Wheatley $(1995,1996)$, who sought to explore possible symbolic reasons for the location of Neolithic long barrows, and Ruggles and Medyckyj-Scott (1996) who offered an implementation of Ruggles et al's. earlier (1993) proposal as a concrete example of the use of GIS to explore ideological determinants of site location. Similarly, Madry and Rakos (1996, p.104) cite the incorporation of "cultural factors" as one of the motivations for their extension to Madry and Crumley's (1990) GIS analysis of Iron Age hillforts.

Like their non-GIS counterparts, successive statistical GIS visibility studies generally show increasing inferential rigour. Wheatley's $(1995 ; 1996)$ analysis of intervisibility among two groups of Neolithic long barrows advanced from earlier studies by explicitly testing a hypothesis. He summed the viewshed maps from each long barrow to produce a cumulative viewshed (times 
seen) map and used a Kolmogorov-Smirnov test to compare the frequency of intervisibility between barrows with the frequency of intervisibility between barrows and non-barrow locations. As a result he claimed to be able, in the case of one group, to refute the Null hypothesis that barrows are located irrespective of the number of other barrows that are visible. However, as he himself noted (1995, p.180), it is important to distinguish association from causation. Fisher et al. (1997) operationalised this distinction in their study of Bronze Age cairn location. Specifically, their use of stratified random sampling to demonstrate that the proportion of sea in the cairn viewsheds was higher than expected by chance, even among locations similarly close to the sea, supports the argument that the desire to overlook sea was a causal rather than coincidental factor in cairn location. Similarly, Lake and Woodman (2000) used stratified random sampling to argue that Mesolithic campsites were located so as to afford larger views than other topographically similar non-site locations.

GIS visibility studies in archaeology have been the subject of a sustained internal critique. The first strand of this critique comprises a catalogue of methodological problems that Wheatley and Gillings (2000, p.2) classify as either procedural (see also van Leusen 1999) or pragmatic. The procedural problems are GIS-specific and mostly have known - albeit often overlookedsolutions. For instance, improved experimental design has included elimination of edge-effects (Lake et al. 1998) as well as recognition (Fisher et al. 1997) and even exploitation (Loots 1997; Woodman 2000) of the lack of reciprocity of line-of-sight. There have also been attempts to gauge the robustness of results by assessing the most appropriate background sample sizes (Lake et al. 1998) and by using probable viewsheds to model the effect of elevation model quality (Loots et al. 1999; Madry and Rakos 1996). Furthermore, computational methods have been devised to automate the process of background sampling (Lake et al. 1998) and to correct for curvature of the earth (Ruggles and Medyckyj-Scott 1996, p.133). The pragmatic problems, which are shared by both GIS and non-GIS visibility studies and include issues such as palaeovegetation and object-background clarity, remain rather less explored (but see Tschan et al. 2000 for an attempt to incorporate palaeovegetation).

The second strand of the critique of archaeological GIS visibility studies is theoretical and in significant part derived from a more general critique of the use of GIS in archaeology. This 
latter in turn mirrors the well known post-Positivist critique of GIS (e.g. Curry 1998), which Sui (1994) describes as having ontological, epistemological, methodological and ethical aspects. Thus, ontologically, Thomas (1993) objects to the way in which, in his view, GIS perpetuates Haraway's (1991, p.189) "God trick", laying "the world bare, like ... the corpse under the pathologist's knife" and so presenting "a picture of past landscapes which the inhabitant would hardly recognise" Thomas (1993, p.25), a point developed in less florid language by Llobera (1996). Similarly, epistemological concerns are reflected in a variant of geography's "'tool' versus 'science" debate (Wright et al. 1997): that GIS applications have, either wittingly (Wheatley 1993, p.133) or unwittingly (Gaffney et al. 1996, p.132) encouraged a functionalist approach to archaeological explanation that had otherwise been largely rejected following the humanistic critique of Processual archaeology. Archaeologists are also alert to the possibility of methodological determinism, for example, in the suggestion that "multiple viewshed analysis is more the product of the methodological possibilities of a GIS than of archaeological theory" (Wansleeben and Verhart 1997, p.61). The ethical critique of GIS (e.g. Curry 1998) is less developed in archaeology than elsewhere, although Thomas (1993, p.25) has suggested that since GIS has "much in common with modern technologies of surveillance and control, we seem to be seeking to monitor and discipline the past."

One of the earliest responses to the humanistic critique of GIS was to focus on visibility as a means of identifying symbolic influences on site location (e.g. Ruggles and Medyckyj-Scott 1996; Wheatley 1996). By equating symbolism and cognition it was possible to argue that this approach, being neither economic nor behaviourist, escaped the alleged environmental or functional determinism of other uses of GIS in archaeology. Some studies in this vein, such as the work of Ruggles and Medyckyj-Scott (1996) discussed earlier, fall comfortably within the remit of Cognitive-Processual archaeology. Others are more ambivalent. For example, Gaffney et als. (1996) use of GIS to revisit Bradley's (1991) essentially Cognitive-Processual 'art as information' approach to the prehistoric monuments of Kilmartin lacks a properly scientific mode of inference. Conversely, Wheatley's (1996) use of hypothesis testing to make inferences about long barrow intervisibility forms part of a paper which approvingly cites the humanistic work of Thomas (1991) among others. Nevertheless, both Gaffney et al. and Wheatley introduce 
'perception' as a way forward, and this has indeed been central to more recent developments (Witcher 1999).

Recent responses to the humanistic critique of GIS visibility studies use the term 'perception' in at least two different ways which roughly mirror Rodaway's (1994, p.10) distinction between the "reception of information" and "mental insight". The first usage typically refers to environmental factors that may inhibit or enhance object recognition. These are among the pragmatic issues identified by Wheatley and Gillings (2000), such as contrast between object and background, atmospheric conditions and direction of illumination. Wheatley and Gillings draw heavily on Higuchi's (1983) indices of the visual environment to suggest ways of making GIS visibility analysis more sensitive to such perceptual constraints. In particular, they present simple "recipes" for using standard GIS functions to decompose the binary viewshed according to distance and directionality (Wheatley and Gillings 2000, pp.16-24). Note, however, that none of these developments in themselves preclude an environmentally determinist approach to human behaviour. Instead, it is the second meaning of 'perception' that is claimed to function as a guarantor of human agency.

This second usage of 'perception' refers to the specifically human factors that influence object recognition. Some of these are physical, such as body-mechanical constraints on field-of-view (Wheatley and Gillings 2000, p.7), while others are cognitive in the sense that cultural preconceptions direct attention to- and classification of- a subset of the total range of environmental stimuli (Wheatley 1993, p.135). Consideration of these factors has led to acknowledgement that visibility is a subjective outcome of human-environment interaction rather than an objective property of the environment itself. This position is broadly congruent with Gibson's (1986) ecological theory of perception. Indeed, researchers have explicitly drawn on Gibson's theory for both theoretical elaboration (Wheatley and Gillings 2000) and the formulation of a methodological response, notably by Llobera $(1996,2001)$. Llobera has developed methods to map visual landscape 'affordances' such as the rate of change of view (1996, p.619) and 'prominence' (2001, p.1007). An important point about Llobera's methods, unlike say Chapman's (2000) calculation of viewsheds along a specific pathway, or the use of virtual reality (e.g. Gillings and Goodrick 1996; Exon et al. 2000), is that they aim to map what the landscape offers from 
every possible location of the viewer and thus, in a sense, provide a comparative background population for the phenomenological wanderings of, for example Tilley (1994).

\section{The Visual Setting of Stone Circles}

This case study is intended to provide an example of the kind of methodological developments that are required for GIS to contribute to current archaeological interest in visibility. Specifically, it seeks to establish whether GIS can be used to measure a property of the settings of some prehistoric stone circles: that the far horizon affords an impression of circularity which in some sense echos the circularity of those monuments. The development of a GIS measure of this property offers two potential benefits. One, which forms the focus of the work reported in the present paper, is that it should provide a means of unpacking what exactly contributes to the impression of circularity and, indeed, whether it is a uniform phenomenon. The other, which is the focus of work to be reported elsewhere, is that such a measure could then be used to establish whether stone circles were preferentially placed in locations which afford an impression of circularity. Hopefully this attempt to quantify a subjective quality of a landscape setting will be of interest, not just to archaeologists, but to all those concerned with visual amenity.

\subsection{Stone circles}

Stone circles rank among the most enigmatic of all prehistoric monuments. Despite their presence in the landscape for over 4000 years we have only the most tenuous understanding of how their landscape setting relates to their role in prehistoric society. Stone circles are found across many parts of England, Ireland, Scotland, Wales and Northern France; they were constructed between the Middle Neolithic and Late Bronze Age (c.3500 BC-1000 BC). In general they consist of a number of large stones or boulders that have been placed to form a roughly circular plan, although their size and form vary considerably with time and from region to region. Many are associated with other prehistoric monuments, for example: standing stones, stone rows and avenues, timber circles, henges, passage graves and ring cairns.

Explanations of the purpose of stone circles range from the romantic and mythical to the scientific (Burl 1979, p.10-11), including: locations for making sacrifices; druidic temples; places 
of assembly; and instruments for calculating and predicting the seasons, or the movement of the sun or the moon (Hawkins 1966). Their form has likewise been attributed to various forces, ranging from the punishment of wrong doers - resulting in the remains of petrified beings forming circles such as The Merry Maidens, The Pipers, and Long Meg and Her Daughters- to their careful layout according to a range of geometric designs and employing a standard unit of measurement known as the megalithic yard (Thom 1967). Explanations for the location of stone circles are equally varied and include: coincidence with the path of ley-lines forming a telepathic network across the landscape (Williams 1968); the actions of prehistoric water diviners (Underwood 1969); centrality within hierarchically organised territories (Renfrew 1973); and most recently the symbolism of the setting (Bradley 1998; Richards 1996).

For most of the history of archaeology the study of stone circles has taken the form of the study of individual sites. Much of the early recording and excavation was carried out in the 18th and 19th Centuries and was poorly documented. As Barnatt (1989, p.1) notes "little attempt was made to synthesise the data as a whole". During the late 20th Century archaeologists began to develop a greater awareness of regional and chronological variability (Burl 1976; Barnatt 1989), although they have perhaps made fewer advances in understanding that variability. Another important strand of research during the 20th Century was work on the astronomical and 'scientific' significance of stone circles. Thom's (1955) suggestion that a 'megalithic yard' was used to measure out geometric designs has been largely discredited (Barnatt 1989, pp.26-29), but subsequent studies of visibility (e.g. Ruggles 1984; Ruggles and Burl 1985; Ruggles et al. 1991; Barnatt 1989; Barnatt and Pierpont 1983) have confirmed the orientation of stone circles with reference to astronomical events, although no particular event has been consistently identified as significant at stone circles generally. As discussed earlier, many of these archaeoastronomical visibility studies fall broadly within the remit of CognitiveProcessual archaeology.

More recent approaches to stone circles (and associated monuments) follow the adoption by many of a more humanistic archaeology. The work of Bradley (1998) and Richards (1996) typifies this approach, in which prehistoric monuments are examined in relation to their landscape setting. Both Bradley and Richards suggest that the forms of certain stone circles "echo 
the characteristic features" of their topographic setting and so provide a "metaphor" for the wider landscape (Bradley 1998, p.122-3). Bradley and Richards have identified some striking examples: Castlerigg stone circle sited with "a facade of standing stones confronting a chain of mountains"; Long Meg and Her Daughters commanding a "virtually continuous horizon of hills and mountains"; the Ring of Brodgar almost surrounded by water and "enclosed by the encircling hills"; and Avebury "ringed by a horizon of hills" (Bradley (1998, p.122) and Richards (1996, p.203)). Although the particularities of each monument strengthen the overall argument, it is nevertheless likely that most visitors would recognise the common feature in these descriptions: that the far (most distant) horizon in some way echos the circularity of the stone circles. The research reported below seeks to identify some relatively simple quantitative measures that are sensitive to this property as it is perceived in the field.

\subsection{Method}

The term 'impression of circularity' has been chosen as a label for the phenomenon that Bradley and Richards describe. This term recognises that while the far horizon may be perceived as circular (in the sense that it either elicits or supports classification as similar in form to a stone circle), no aspect of the topography need actually demonstrate patterning on a fixed radius. Thus the methodological problem facing a user of GIS is to identify what measurable properties of the environment interact to create the impression of circularity and, second, to develop a spatial operation capable of producing a summary measure of that interaction. There appear to be at least two possible approaches to this problem. The first would be to measure concavity, as described by Yokoyama et al. (2002), on the grounds that a stone circle located at the focal point of a concave landform would be surrounded by higher land and thus have a circular horizon. This measure has been rejected following a series of visits to each of the monuments mentioned by Bradley and Richards. In particular, concavity is calculated using a specified radial distance, whereas it was observed that in many cases the actual distance from the monument to the far horizon varied considerably from one segment to the next. The second approach, adopted here, is to assume that the required measure can be calculated as a function of one or more properties of the locations that fall on the far horizon and/or the geometric 
relations between those locations and the stone circle. This obviously requires a method for calculating the far horizon.

Most well known GIS software packages do not implement a function to calculate the position of the far horizon from a given viewpoint, which is perhaps surprising given that calculation of the viewshed is one of the most common operations in GIS which handle digital elevation data (Fisher 1996). As a result, one of the authors has written a suitable function for the GRASS GIS software package. The algorithm is different from that proposed by Fisher (1996, p.38) and will be reported in detail elsewhere. For present purposes it is sufficient to note that this function produces a raster map of horizon map cells, coded by the azimuth at which they are visible, along with an additional map which distinguishes those cells that fall on the far horizon from those that fall on nearer 'local' horizons. All the analyses reported here were conducted using far horizon cells only. (Note that 'far horizon' is hereafter abbreviated as 'horizon'.) For the sake of convenience, the function can also output a list, sorted in order of increasing azimuth, giving the azimuth, inclination (the vertical angle of view from eye to horizon, derived from the viewshed $\mathrm{map}^{2}$ ) and distance at which each horizon cell is visible, along with its elevation (derived from the digital elevation model). These lists were used to create the 'panoramic' graphs discussed below (e.g. figure 5). It is important to note that, for purely geometric reasons, the number of map cells covered by the horizon in any given segment of fixed angle depends upon the distance of the horizon from the viewpoint, which makes it difficult to interpret relative frequencies of horizon cell properties. Consequently, the summary statistics and empirical cumulative distribution functions discussed below are not directly derived from the lists of horizon cells. Instead, they are based on estimates (derived from the data in the lists) of the properties of the horizon at uniformly incremented azimuths from 0-360 degrees. The azimuthal increment of 0.5 degrees was chosen to ensure that for at least two thirds of stone circles the mean distance to the horizon is such that the length of the horizon corresponding to the azimuthal increment is equal or greater than the map cell size.

The new GIS function just described has been used to calculate the horizons of 19 recumbent

\footnotetext{
${ }^{2}$ Those familiar with GRASS should note that the viewshed function (r.los) was modified to return floating point rather than integer inclination values.
} 
stone circles in Grampian, Scotland. These circles comprise a number of monoliths graded in height towards two large upright stones that flank a massive (recumbent) stone laid horizontally on the southwest edge. Recent excavations by Bradley et al. (2002) suggest that the construction of the actual stone circles at these sites occured relatively late in a long sequence of activities that typically included the enclosure of a preexisting cremation pyre in a low cairn. The decision to analyse recumbent stone circles was solely pragmatic and does not reflect a priori knowledge that their locations exhibit a greater impression of circularity than is present at other types of stone circle; indeed, it has been argued by Ruggles and Burl (1985) that their location was at least partly determined by astronomical considerations, since in many cases the large horizontal recumbent stone and its associated vertical flanking stones would have framed the moon when it was low in the midsummer sky. Rather, recumbent stone circles were chosen for this study because their exceptionally high density in an area of varied topography offers an ideal laboratory in which to develop a GIS measure of the impression of circularity. The 19 circles listed in table 1 were selected for analysis because 8 figure $^{3}$ grid references are available for them. The GIS analyses were conducted using an Ordnance Survey Landform Panorama digital elevation model with a cell size of $50 \mathrm{~m}$. The viewsheds were calculated up to a maximum radius of $40 \mathrm{~km}$, which in every case appears to contain $100 \%$ or very close to $100 \%$ of the horizon.

Before reporting the results it is worth emphasising that while the purpose of this study is to establish whether GIS can be used to measure the degree to which certain locations create an impression of circularity, it seeks to do so in a relative rather than absolute sense. This is because in the absence of appropriate psychometric research there are no real-world exemplars of 'not at all circular' and 'completely circular' with which to calibrate the GIS measures. Even if such research were undertaken, it is likely that the majority of applications would still seek to compare rather than provide absolute characterisation. For example, a comparative measure of the impression of circularity would be adequate for establishing whether stone circle locations were drawn non-randomly from a background population in that respect.

\footnotetext{
${ }^{3}$ I.e. location to the nearest $10 \mathrm{~m}$
} 


\subsection{Results}

The full set of horizon maps demonstrate the variety of planar horizon shapes exhibited by the locations of the 19 recumbent stone circles. Figure 1 shows a selection of horizon maps chosen to illustrate this variety; in all cases the viewpoint is the stone circle. These maps provide a visual impression of the planar location of the horizon relative to the viewpoint, that is, whether the horizon is distant or close. They also show whether the horizon is continuous in plan, in the sense that the distance from the viewpoint varies continuously with increasing azimuth as opposed to discontinuously. The advantage of a raster horizon map is that it clearly depicts a continuous horizon as a set of contiguous cells and a discontinuous horizon as a set of dispersed cells. Sunhoney has the closest and probably least dispersed horizon, while that visible from Tomnaverie is more distant, but still largely contiguous. At the other end of the spectrum, the horizons visible from Easter Aquorthies and Loanhead of Daviot are both very variable in distance and also very dispersed. The planar shape of Old Keig's horizon appears to fall somewhere between the extremes represented by these four sites; for the most part its horizon is at a similar distance to that of Tomnaverie, but it is more dispersed.

Maps such as those just described are useful in their own right, but they do not harness the full potential of GIS for aiding comparison of large numbers of monuments and, in particular, aiding the comparison of monuments and a background sample of non-monument locations (which as noted above, we are undertaking and will report elsewhere). For this it is necessary to move beyond the horizon maps to quantitative measures that capture the impression of circularity afforded by a given horizon. Points on the horizon of any given stone circle, indeed any location, vary in ways that may be measured in terms of their distance from the viewpoint, elevation relative to sea level ${ }^{4}$, and/or inclination.

Figures 2, 3 and 4 graph, for all 19 stone circles, the empirical cumulative distribution functions of the distance, elevation, and inclination respectively of each 0.5 degree segment of the horizon visible from each monument. Figures 5-7 show, for each of the stone circles discussed below, how the distance, elevation and inclination vary (moving from left to right) as

\footnotetext{
${ }^{4}$ Relative elevation may also merit investigation, but was not considered here as it is almost certainly more relevant to concavity than circularity per se.
} 
one follows the horizon from from due North in a clockwise direction. Table 1 lists the mean and standard deviation (sd) of each of the measures for each stone circle. The utility of each measure considered in turn.

As one would expect, the empirical cumulative distribution functions (figures 2-4), azimuthal variability (figures 5-7) and summary statistics (table 1) of distance confirm the visual impressions already gained from figure 1. Sunhoney has the closest horizon, as is demonstrated by its far left position on the graph in figure 2, the values recorded in the distance graph (figure 6) and the lowest mean distance $(3721 \mathrm{~m})$ to the horizon. In contrast, parts of the horizons visible from Loanhead of Daviot, Easter Aquorthies and, to a lesser extent, Old Keig lie at a substantial distance, as shown by their far right position on the graph in figure 2, in the values recorded in the distance graphs (figures 5 and 6) and in the mean distances of $9646 \mathrm{~m}, 10479 \mathrm{~m}$ and $8130 \mathrm{~m}$ respectively. The horizon visible from Tomnaverie has a distribution of distances that falls somewhere in the middle of the envelope defined by the empirical cumulative distribution function curves in figure 2; it also has a roughly mid-range mean horizon distance of $6482 \mathrm{~m}$.

The stone circles which have highly fluctuating distances to their horizons (as seen in figures 5-7 and the standard deviation values) are also those which exhibit a very dispersed horizon in the maps, for example: Loanhead of Daviot $(\mathrm{sd}=9849 \mathrm{~m})$ and Easter Aquorthies $(\mathrm{sd}=11385 \mathrm{~m})$ followed by Old Keig $(\mathrm{sd}=8047 \mathrm{~m})$. In contrast, Sunhoney $(\mathrm{sd}=4,942 \mathrm{~m})$ and Tomnaverie ( $\mathrm{sd}=6,016 \mathrm{~m}$ ) have a significantly lower level of fluctuation, which seems consistent with field observations that Sunhoney and Tomnaverie are located in circular landscapes.

The second measure considered is elevation. Figure 3 indicates that the stone circles at Easter Aquorthies, Loanhead of Daviot and Sunhoney have the lowest average horizon elevations, with mean values of $229 \mathrm{~m}, 231 \mathrm{~m}$ and $239 \mathrm{~m}$ respectively. Note that the left edge of the envelope containing all distributions is skewed by the inclusion of two stone circles whose horizons extend over the sea, which has an elevation of $0 \mathrm{~m}$. At the other extreme, the horizons visible from Tomnaverie and Old Keig have high mean elevation values: $393 \mathrm{~m}$ and $431 \mathrm{~m}$ respectively.

From field observation it was noted that both the variability and magnitude of the perceived elevation of the horizon is an important factor in the creation of an impression of circularity. 
In particular, low variability in perceived elevation can create an impression of circularity even where the horizon is not located at a consistent distance from the viewpoint. However, in the case of the stone circles discussed above the actual elevation of the horizon fluctuates greatly as one turns through 360 degrees (see figures $5-7$ and the standard deviations in table 1). The magnitude of this fluctuation is least at Sunhoney $(\mathrm{sd}=83 \mathrm{~m})$ and Loanhead of Daviot $(\mathrm{sd}=94 \mathrm{~m})$, and greatest at Tomnaverie $(\mathrm{sd}=192 \mathrm{~m})$ and Old Keig $(\mathrm{sd}=123 \mathrm{~m})$, with Easter Aquorthies $(\mathrm{sd}=105 \mathrm{~m})$ lying somewhere between. On the face of it this result is not compatible with the field observations, noted earlier, that the horizon visible from Tomnaverie creates an impression of circularity, whereas the horizon visible from Loanhead of Daviot creates less of an impression of circularity.

So far the results indicate that an impression of circularity due to low variability in perceived elevation does not necessarily correlate with low variability of true elevation. This suggests that the measures of distance and elevation should be combined to provide a means of quantifying the perceived elevation, as distinct from the true elevation, of the horizon. As it turns out, inclination has appropriate properties for this task. For example, the field observation that the horizon visible between 30 and 200 degrees around Easter Aquorthies is reasonably level is replicated by the inclination values in figure 5, even though the true elevation fluctuates markedly. In this particular case an inverse relationship between distance and elevation gives rise to very low variability in perceived elevation. As well as providing a suitable measure of the variability in perceived elevation, inclination also measures the magnitude of perceived elevation. In particular, an inclination above 90 degrees indicates that the horizon gives the impression of being higher than the site.

During field observation Tomnaverie and Sunhoney elicited the strongest impressions of circularity, Old Keig moderately so, and Loanhead of Daviot and Easter Aquorthies less so. The graphs shown in Figures 5-7 and summary statistics in table 1 reveal that the magnitude of inclination reflects these results. Sunhoney and Tomnaverie have horizons with high mean inclination (93.07 and 92.88 degrees respectively), while Easter Aquorthies and Loanhead of Daviot have horizons with low mean inclinations (91.30 and 90.79 degrees respectively). The mean inclination for Old Keig falls between these (91.99 degrees). Interpretation of the variability 
in inclination is less straightforward. The standard deviation of the inclination of the horizon visible from Sunhoney is greater (1.87 degrees) than that of the horizon visible from Loanhead of Daviot (0.7 degrees). On the other hand, the decreased standard deviation of inclination at Tomnaverie (1.13 degrees) compared with Sunhoney does reflect the greater impression of circularity at the former. It may be that the most useful comparisons of variability are those between stone circles that fall within similar bands of mean magnitude. Figure 4 graphs the empirical cumulative distribution functions of inclination for horizons visible from each of the 19 stone circles. Although it clearly demonstrates the wide variation between horizons, closer examination also reveals useful patterns. As might be expected from the mean inclinations just discussed, the curves for Tomnaverie and Sunhoney fall on the righthand margin of the envelope of curves in the graph, while that for Loanhead of Daviot falls towards the lefthand margin of the envelope. Similarly, the declining standard deviations of inclination at Sunhoney, Tomnaverie and Loanhead of Daviot are reflected in the decreasing average gradients of their curves.

These initial results strongly suggest that the inclination at which locations on the horizon are visible from a given viewpoint provides useful information about the impression of circularity created by the topographic setting of that viewpoint. Although the mean inclination correlates particularly well with the impression of circularity, the empirical cumulative distribution functions are also informative. In particular, it appears that they may allow one to distinguish locations that create an impression of circularity by virtue of: 1) low variability despite low perceived elevation (steep curves on the lefthand side of the envelope); ii) high perceived elevation despite high variability (shallow curves on the righthand side of the envelope); and iii) high perceived elevation with low variability (steep curves on the righthand side of the envelope). If confirmed by further scrutiny, this will provide a means for archaeologists (and others) to communicate more explicitly what it is about a location that creates an impression of circularity. 


\section{Conclusion}

This paper has demonstrated that the history of GIS visibility studies in archaeology mirrors the development of archaeological theory. In particular, the archaeological literature on the application of GIS reads in many respects as a resume of the wider Processual-Post Processual debate in archaeology. A consistent theme in more recent contributions to this literature has been the exhortation to develop appropriate methods for archaeological questions, rather than ignoring those questions or even modifying them to suit the technology (Fisher 1999; Lake et al. 1998; Lock 2000; Tschan et al. 2000; Wheatley and Gillings 2000). The case study reported above was undertaken in that spirit, although the specific question was deliberately chosen for the likelihood that it would also interest a wider audience concerned with, for example, visual amenity. The results suggest that it is possible to use GIS software to compare a subjective property of different locations in the landscape: the impression of circularity afforded by their topographic setting. In this case an algorithm was developed to retrieve the mean, standard deviation and empirical cumulative distribution functions of the inclination at which points on the horizon are visible from a specified viewpoint. This was applied to 19 recumbent stone circles and it was found that the two summary statistics and distribution function are sensitive to variability in the impression of circularity afforded by the location of those monuments, as observed in the field. Furthermore, it appears that the empirical cumulative distribution function of inclinations provides a useful tool for 'unpacking' what archaeologists mean when they claim that certain locations share an impression of circularity. This should greatly facilitate comparative studies of stone circles and other monuments. In addition, by providing a means of comparing the locations of stone circles with the wider population from which they are drawn, these measures should help archaeologists to investigate whether stone circles were preferentially placed in locations which afford an impression of circularity.

\section{Acknowledgements}

We are grateful to the editors for their invitation to contribute an archaeological case study to this thematic issue. We are also grateful for the comments of three anonymous reviewers. 


\section{References}

Aldenderfer, M. (1996). Introduction. In Aldenderfer, M. and Maschner, H. D. G., editors, Anthropology, Space and Geographical Information Systems, pages 3-18. Oxford University Press, New York.

Barnatt, J. (1989). Stone Circles of Britain: Taxonomic and Distributional Analyses and a Catalogue of Sites in England, Scotland and Wales, volume 215 of British Archaeological Reports British Series. British Archaeological Reports, Oxford.

Barnatt, J. and Pierpont, S. (1983). Stone circles: Observatories or ceremonial centres? Scottish Archaeological Review, 2:101-115.

Barrett, J. C. (1994). Fragments from Antiquity: an Archaeology of Social Life in Britain, 2900-1200 BC. Blackwell, Oxford.

Batchelor, D. (1999). The use of GIS for archaeological sensitivity and visibility analysis at Stonehenge, Avebury and associated sites, World Heritage site, United Kingdom. In Box, P., editor, GIS and Cultural Resource Management: A Manual for Heritage Managers, pages 118-128. UNESCO, Bangkok.

Bender, B., Hamilton, S., and Tilley, C. (1997). Leskernick: Stone worlds; alternative narratives; nested landscapes. Proceedings of the Prehistoric Society, 63:147-78.

Bradley, R. (1991). Rock art and the perception of landscape. Cambridge Archaeological Journal, $1: 77-101$.

Bradley, R. (1994). Symbols and signposts - understanding the prehistoric petroglyphs of the British Isles. In Renfrew, C. and Zubrow, E. B. W., editors, The Ancient Mind: Elements of a Cognitive Archaeology, pages 95-106. Cambridge University Press, Cambridge.

Bradley, R. (1998). The Significance of Monuments: On the Shaping of Human Experience in Neolithic and Bronze Age Europe. Routledge, London.

Bradley, R., Ball, C., Croft, S., and Philips, T. (2002). The stone circles of northeast Scotland in the light of excavation. Antiquity, 76:840-848. 
Bradley, R., Harding, J., and Mathews, M. (1993a). The siting of prehistoric rock art in Galloway, south-west Scotland. Proceedings of the Prehistoric Society, 59:269-283.

Bradley, R., Harding, J., Rippon, S., and Mathews, M. (1993b). A field method for investigating the distribution of rock art. Oxford Journal of Archaeology, 12:129-145.

Burl, A. (1976). The Stone Circles of the British Isles. Yale University Press, London.

Burl, A. (1979). Rings of Stone: The Prehistoric Stone Circles of Britain and Ireland. Book Club Associates, London.

Chapman, H. (2000). Understanding wetland archaeological landscapes: GIS, environmental analysis and landscape reconstruction; pathways and narratives. In Lock, G., editor, Beyond the Map: Archaeology and Spatial Technologies, pages 49-59. IOS Press, Amsterdam.

Chorley, R. J. and Haggett, P., editors (1967). Models in Geography. Methuen, London.

Clarke, D. L. (1968). Analytical Archaeology. Methuen, London.

Clarke, D. L., editor (1972). Models in Archaeology. Methuen, London.

Curry, M. R. (1998). Digital Places: Living with Geographic Information Technologies. Routledge, London.

Devereux, P. (1991). Three-dimensional aspects of apparent relationships between selected natural and artificial features within the topography of the Avebury complex. Antiquity, 65:894-898.

Drewett, P., editor (1982). The Archaeology of Bullock Down, Eastbourne, East Sussex: The Development of a Landscape. The Sussex Archaeological Society, Lewes.

Edmonds, M., Thomas, J., et al. (1990). Papers from the Theoretical Archaeology Group (TAG) Conference, Newcastle 1989. Scottish Archaeological Review, 7:1-36.

Exon, S., Gaffney, V., Woodward, A., and Yorston, R. (2000). Stonehenge Landscapes. Archaeopress, Oxford. 
Fisher, P. F. (1996). Reconsideration of the viewshed function in terrain modelling. Geographical Systems, 3:33-58.

Fisher, P. F. (1999). Geographical information systems: Today and tomorrow? In Gillings, M., Mattingly, D., and van Dalen, J., editors, Geographical Information Systems and Landscape Archaeology, volume 3 of The Archaeology of Mediterranean Landscapes, pages 5-12. Oxbow Books, Oxford.

Fisher, P. F., Farrelly, C., Maddocks, A., and Ruggles, C. (1997). Spatial analysis of visible areas from the Bronze Age cairns of Mull. Journal of Archaeological Science, 24:581-592.

Fraser, D. (1983). Land and society in Neolithic Orkney, volume 117 of British Series. British Archaeological Reports, Oxford.

Fraser, D. (1988). The orientation of visibility from the Chambered Cairns of Eday, Orkney. In Ruggles, C. L. N., editor, Records in Stone, pages 325-337. Cambridge University Press, Cambridge.

Gaffney, V. and Stančič, Z. (1991). GIS Approaches to Regional Analysis: a Case Study of the Island of Hvar. Znanstveni inštitut Filozofske fakultete, Ljubljana.

Gaffney, V. and Stančič, Z. (1992). Diodorus siculus and the island of Hvar, Dalmatia: Testing the text with GIS. In Lock, G. and Moffett, J., editors, Computer Applications and Quantitative Methods in Archaeology 1991, number 577 in British Archaeological Reports International Series, pages 113-126. Tempvs Reparatvm, Oxford.

Gaffney, V., Stančič, Z., and Watson, H. (1996). Moving from catchments to cognition: Tentative steps toward a larger archaeological context for GIS. In Aldenderfer, M. and Maschner, H. D. G., editors, Anthropology, Space and Geographic Information Systems, pages 132-154. Oxford University Press.

Gibbon, G. (1989). Explanation in Archaeology. Basil Blackwell, Oxford.

Gibson, J. J. (1986). The Ecological Approach to Perception. Lawrence Erlbaum Associates, Hillsdale, New Jersey. 
Gillings, M. and Goodrick, G. T. (1996). Sensuous and reflexive GIS: Exploring visualisation and VRML. Internet Archaeology, 1. http://intarch.ac.uk/journal/issue1/gillings_index.html.

Haggett, P. (1965). Locational Analysis in Human Geography. John Wiley, New York, 1st edition.

Haraway, D. (1991). Simians, Cyborgs, and Woman: The Reinvention of Nature. Free Association Books, London.

Hawkins, G. S. (1966). Stonehenge Decoded. Souvenir Press, London.

Higuchi, T. (1983). The Visual and Spatial Structure of Landscapes. MIT Press, Cambridge, Massachusetts. Translated by Charles S. Terry.

Hodder, I. (1986). Reading the Past. University Press, Cambridge.

Krist, F. J. and Brown, D. G. (1994). GIS modelling of‘ Palaeo-Indian period caribou migrations and viewsheds in northeastern Lower Michigan. Photogrammetric Engineering and Remote Sensing, 60:1129-1137.

Lake, M. W. and Woodman, P. E. (2000). Viewshed analysis of site location on Islay. In Mithen, S. J., editor, Hunter-Gatherer Landscape Archaeology: The Southern Hebrides Mesolithic Project, 1988-98, volume 2: Archaeological Fieldwork on Colonsay, Computer Modelling, Experimental Archaeology, and Final Interpretations, pages 497-503. The McDonald Institute for Archaeological Research, Cambridge.

Lake, M. W., Woodman, P. E., and Mithen, S. J. (1998). Tailoring GIS software for archaeological applications: An example concerning viewshed analysis. Journal of Archaeological Science, 25:27-38.

Llobera, M. (1996). Exploring the topography of mind: GIS, social space and and archaeology. Antiquity, 70:612-22.

Llobera, M. (2001). Building past landscape perception with GIS: Understanding topographic prominence. Journal of Archaeological Science, 28:1005-1014. 
Lock, G., editor (2000). Beyond the Map: Archaeology and Spatial Technologies. IOS Press, Amsterdam.

Loots, L. (1997). The use of projective and reflective viewsheds in the analysis of the Hellenistic city defence system at Sagalassos, Turkey. Archaeological Computing Newsletter, 49:12-16.

Loots, L., Nackaerts, K., and Waelkens, M. (1999). Fuzzy viewshed analysis of the Hellenistic city defence system at Sagalassos, Turkey. In Dingwall, L., editor, Archaeology in the age of the internet : CAA 97: Computer Applications and Quantitative Methods in Archaeology : proceedings of the 25th anniversary conference, University of Birmingham, April 1997, volume 750 of British Archaeological Reports International Series, page ?? Archaeopress, Oxford.

Madry, S. and Rakos, L. (1996). Line-of-sight and cost surface techniques for regional archaeological research in the Arroux River Valley. In Maschner, H. D. G., editor, New Methods, Old Problems: Geographic Information Systems in Modern Archaeological Research, pages 104-126. Southern Illinois University Center for Archaeological Investigations, Carbondale.

Madry, S. L. H. and Crumley, C. L. (1990). An application of remote sensing and GIS in a regional archaeological settlement pattern analysis: The Arroux River valley, Burgundy, France. In Allen, K. M. S., Green, S. W., and Zubrow, E. B. W., editors, Interpreting Space: GIS and Archaeology, pages 364-380. Taylor \& Francis, London.

Ozawa, K., Kato, T., and Tsude, H. (1995). Detection of beacon networks between ancient hillforts using a digitial terrain model based gis. In Huggett, J. and Ryan, N., editors, Computer Applications and Quantitative Methods in Archaeology 1994. British Archaeological Reports (Int. series) 600, Oxford.

Relph, E. (1976). Place and Placelessness. Pion, London.

Renfrew, C. (1973). Monuments, mobilisation and social organisation in Neolithic Wessex. In Renfrew, C., editor, The Explanation of Culture Change, pages 539-558. Duckworth, London.

Renfrew, C. (1976). Megaliths, territories and populations. In Laet, S. J. D., editor, Acculturation and Continuity in Atlantic Europe, Mainly During the Neolithic period and the Bronze Age, pages 198-220. De Tempel, Brugge. 
Renfrew, C. (1982). Towards an Archaeology of Mind (Inaugral Lecture to the University of Cambridge). University Press, Cambridge.

Renfrew, C. (1994). Towards a cognitive archaeology. In Renfrew, C. and Zubrow, E. B. W., editors, The Ancient Mind: Elements of a Cognitive Archaeology, pages 3-12. Cambridge University Press, Cambridge.

Richards, C. (1996). Monuments as landscape: Creating the centre of the world in late Neolithic Orkney. World Archaeology, pages 190-208.

Rodaway, P. (1994). Sensuous Geographies: Body, Sense and Place. Routledge, London.

Roese, H. (1980). Some aspects of topographical location of Neolithic and Bronze Age monuments in Wales, 1: Menhirs. Bulletin of the Board of Celtic Studies, (28):645-655.

Ruggles, C. L. N. (1984). A new study of the Aberdeenshire recumbent stone circles, 1: Site data. Archaeoastonomy, 6:55-79.

Ruggles, C. L. N. and Burl, H. A. W. (1985). A new study of the Aberdeenshire recumbent stone circles, 2: Interpretation. Archaeoastronomy, 8:25-60.

Ruggles, C. L. N., Martlew, R., and Hinge, P. (1991). The North Mull Project (2): the wider astronomical significance of the sites. Archaeoastronomy, 16:51-75.

Ruggles, C. L. N. and Medyckyj-Scott, D. J. (1996). Site location, landscape visibility, and symbolic astronomy: A Scottish case study. In Maschner, H. D. G., editor, New Methods, Old Problems: Geographic Information Systems in Modern Archaeological Research, number 23 in Occasional Paper, pages 127-146. Southern Illinois University Center for Archaeological Investigations, Carbondale.

Ruggles, C. L. N., Medyckyj-Scott, D. J., and Gruffydd, A. (1993). Multiple viewshed analysis using gis and its archaeological application: A case study in northern mull. In Andresen, J., Madsen, T., and Scollar, I., editors, Computing the Past, pages 125-132. University Press, Aarhus.

Shanks, M. and Tilley, C. (1987). Re-Constructing Archaeology. University Press, Cambridge. 
Sui, D. Z. (1994). GIS and urban studies: Positivism, post-positivism and beyond. Urban Geography, 15:258-278.

Thom, A. (1955). A statistical examination of the megalithic sites in Britain. Journal of the Royal Statistical Society, 118:275-295.

Thom, A. (1967). Megalithic Sites in Britain. Clarendon Press, Oxford.

Thomas, J. (1991). Rethinking the Neolithic. University Press, Cambridge.

Thomas, J. (1993). The politics of vision and the archaeologies of landscape. In Bender, B., editor, Landscape: politics and perspectives, pages 19-48. Berg, Oxford.

Tilley, C. (1994). A Phenomenology of Landscape. Paths, Places and Monuments. Berg, Oxford.

Tschan, A. P., Raczkowski, W., and Latałowa, M. (2000). Perception and viewsheds: Are they mutually inclusive? In Lock, G., editor, Beyond the Map: Archaeology and Spatial Technologies, pages 28-48. IOS Press, Amsterdam.

Tuan, Y.-F. (1977). Space and Place: The Perspective of Experience. Arnold, London.

Underwood, G. (1969). The Pattern of the Past. Museum Press, London.

van Leusen, P. M. (1993). Cartographic modelling in a cell-based GIS. In Andresen, J., Madsen, T., and Scollar, I., editors, Computing the Past: Computer Applications and Quantitative Methods in Archaeology 1992, pages 105-123. University Press, Aarhus.

van Leusen, P. M. (1999). Viewshed and cost surface analysis using GIS (cartographic modelling in a cell-based GIS II). In New Techniques for Old Times-CAA98-Computer Applications and Quantitative Methods in Archaeology: Proceedings of the 26th Conference, Barcelona 1998, number 757 in International Series, pages 215-223. British Archaeological Reports, Oxford.

Wansleeben, M. and Verhart, L. (1997). Geographical information systems: Methodological progress and theoretical decline. Archaeological Dialogues, 1:53-70. 
Wheatley, D. (1993). Going over old ground: GIS, archaeological theory and the act of perception. In Andresen, J., Madsen, T., and Scollar, I., editors, Computing the Past: Computer Applications and Quantitative Methods in Archaeology 1992, pages 133-138. Aarhus University Press, Aarhus.

Wheatley, D. (1995). Cumulative viewshed analysis: A GIS-based method for investigating intervisibility, and its archaeological application. In Lock, G. and Stančič, Z., editors, Archaeology and Geographical Information Systems, pages 171-186. Taylor \& Francis, London.

Wheatley, D. (1996). The use of GIS to understand regional variation in earlier Neolithic Wessex. In Maschner, H. D. G., editor, New Methods, Old Problems: Geographic Information Systems in Modern Archaeological Research, number 23 in Occasional Paper, pages 75-103. Southern Illinois University Center for Archaeological Investigations, Carbondale.

Wheatley, D. and Gillings, M. (2000). Vision, perception and GIS: Developing enriched approaches to the study of archaeological visibility. In Lock, G., editor, Beyond the Map: Archaeology and Spatial Technologies, pages 1-27. IOS Press, Amsterdam.

Williams, W. G. (1968). Stone age circles 'form pattern of power'. Daily Telegraph, 23rd September, 1968.

Witcher, R. (1999). GIS and landscapes of perception. In Gillings, M., Mattingly, D., and van Dalen, J., editors, Geographical Information Systems and Landscape Archaeology, volume 3 of The Archaeology of Mediterranean Landscapes, pages 13-22. Oxbow Books, Oxford.

Woodman, P. E. (2000). Beyond significant patterning, towards past intentions: The location of Orcadian chambered tombs. In Buck, C., Cummings, V., Henley, C., Mills, S., and Trick, S., editors, Proceedings of the UK Chapter of Computer Applications and Quantitative Methods in Archaeology 1999, volume 844 of British Archaeological Reports International Series, pages 91-105. Archaeopress, Oxford.

Wright, D. J., Goodchild, M. F., and Proctor, J. D. (1997). Demystifying the persistent ambiguity of GIS as "tool" versus "science". The Annals of the Association of American Geographers, $87: 346-362$. 
Yokoyama, R., Shirasawa, M., and Pike, R. J. (2002). Visualizing topography by openness: A new application of image processing to digital elevation models. Photogrammetric Engineering and Remote Sensing, 68:257-265. 


\section{Tables}

Table 1: Summary statistics of the properties of each 0.5 degree azimuthal segment of the horizon

\begin{tabular}{|c|c|c|c|c|c|c|}
\hline & \multicolumn{2}{|c|}{ Inclination } & \multicolumn{2}{|c|}{ Distance } & \multicolumn{2}{|c|}{ Elevation } \\
\hline & Mean & Std. & Mean & Std. & Mean & Std. \\
\hline & & Dev. & & Dev. & & Dev. \\
\hline Aikey Brae & 90.39 & 0.62 & 14430.0 & 13729.0 & 124.6 & 68.4 \\
\hline Easter Aquorthies & 91.30 & 1.34 & 10479.0 & 11385.0 & 229.1 & 105.2 \\
\hline Ardlair & 91.32 & 0.76 & 8859.0 & 6453.6 & 403.5 & 107.3 \\
\hline Arnhill & 91.65 & 1.00 & 6797.0 & 5253.6 & 258.2 & 86.6 \\
\hline Berrybrae & 90.51 & 0.53 & 9196.6 & 14797.0 & 54.8 & 5.5 \\
\hline Cothiemur & 92.5 & 1.37 & 6457.0 & 8188.4 & 359.9 & 124.1 \\
\hline Esslie the Greater & 92.63 & 1.37 & 6288.1 & 9122.7 & 330.0 & 139.2 \\
\hline Esslie the Lesser & 92.41 & 1.49 & 5607.3 & 8530.8 & 315.5 & 133.9 \\
\hline Castle Frazer & 91.36 & 0.90 & 8059.0 & 6848.9 & 268.0 & 126.5 \\
\hline Garrol Wood & 91.79 & 0.94 & 8461.0 & 10112.2 & 381.3 & 119.8 \\
\hline Loanhead of Daviot & 90.79 & 0.77 & 9646.0 & 9849.2 & 231.0 & 94.5 \\
\hline Midmar Kirk & 91.77 & 1.44 & 5918.9 & 7296.0 & 285.7 & 110.8 \\
\hline Old Keig & 91.99 & 1.56 & 8130.0 & 8047.0 & 398.4 & 123.0 \\
\hline Rothiemay & 92.14 & 1.17 & 5245.0 & 6955.1 & 248.7 & 121.6 \\
\hline Strichen & 90.85 & 0.58 & 3768.0 & 5229.8 & 123.8 & 40.0 \\
\hline Sunhoney & 93.1 & 1.88 & 3721.0 & 4942.9 & 239.7 & 83.0 \\
\hline Tomnaverie & 92.88 & 1.14 & 6482.0 & 6016.1 & 431.2 & 192.3 \\
\hline Whitehill & 93.07 & 3.51 & 10488.3 & 11989.5 & 314.0 & 111.7 \\
\hline Yonder Bognie & 92.01 & 1.47 & 4308.0 & 5200.2 & 220.8 & 99.5 \\
\hline
\end{tabular}




\section{Figures}

Figure 1: Horizon Maps (C)Crown Copyright Ordnance Survey. An EDINA/JISC supplied service)
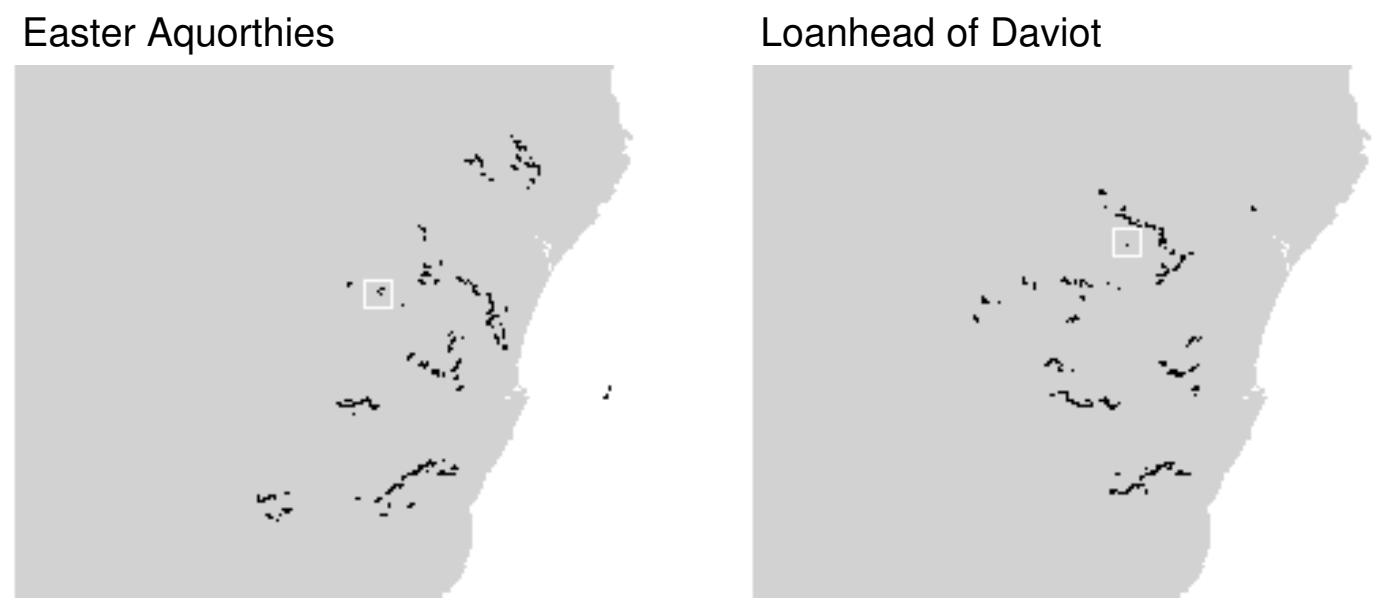

Old Keig

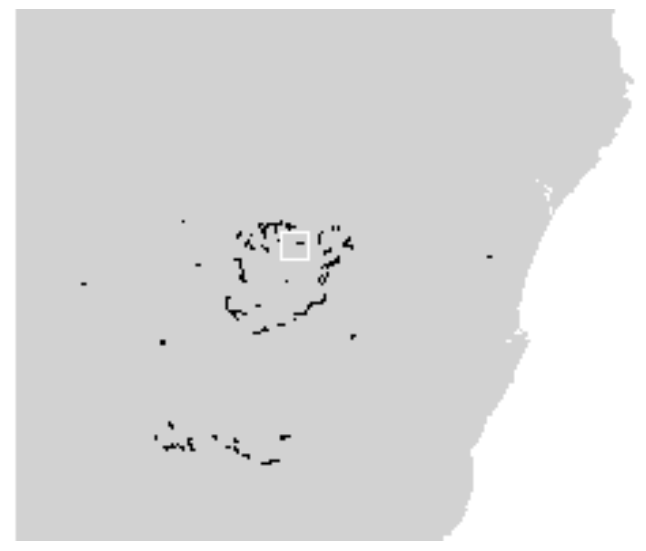

Tomnaverie

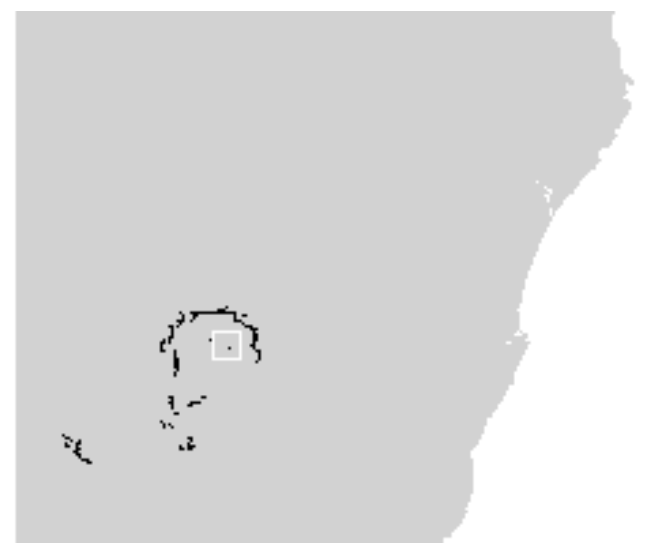

Sunhoney

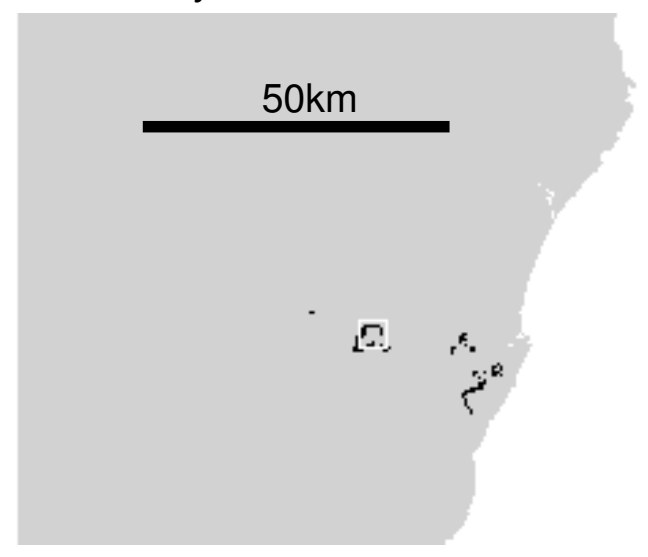

Sunhoney (detail)

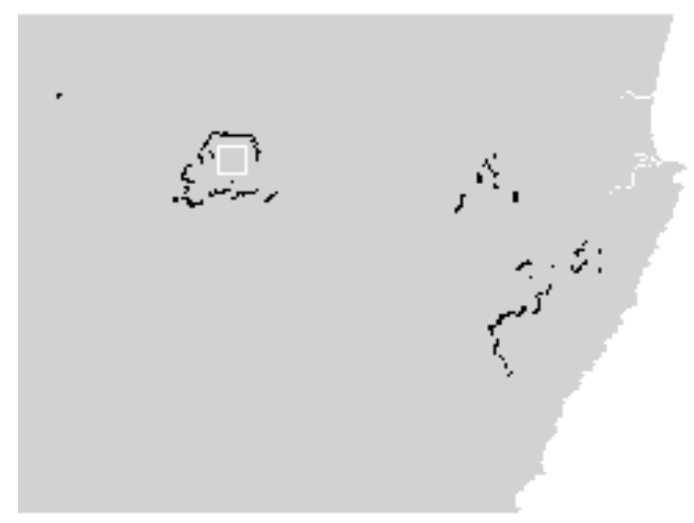


Figure 2: Empirical cumulative distribution function of distance

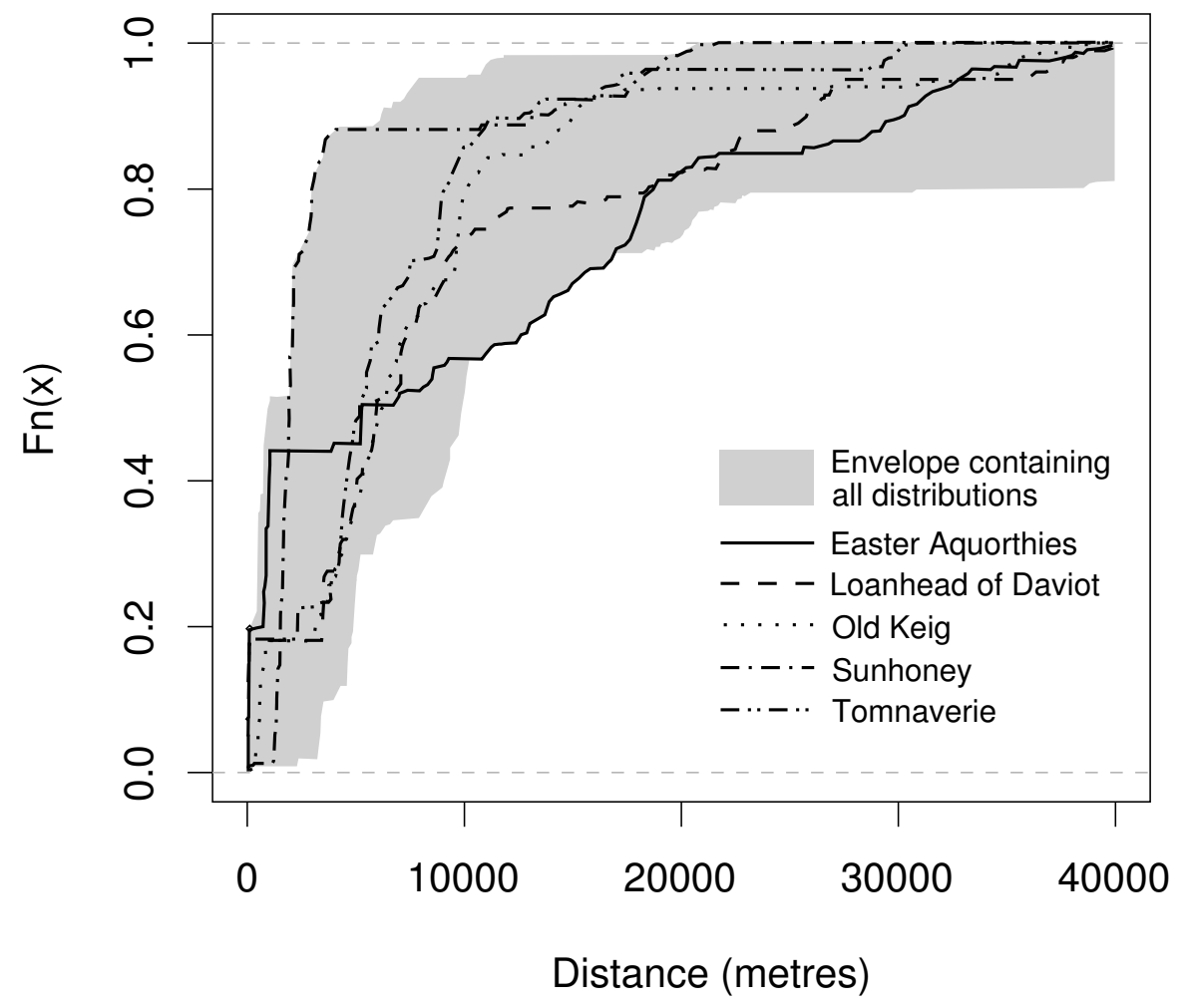

Figure 3: Empirical cumulative distribution function of elevation

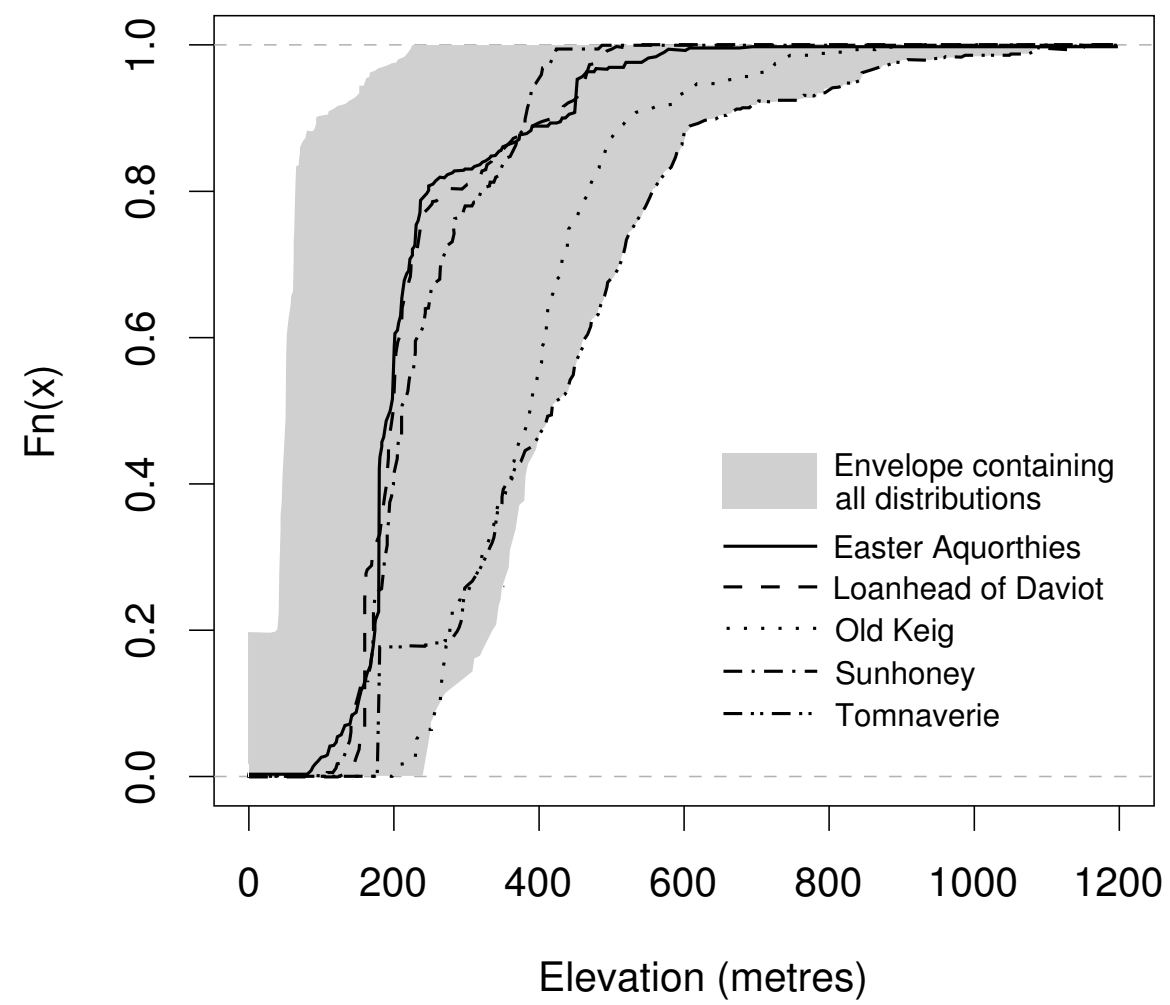


Figure 4: Empirical cumulative distribution function of inclination

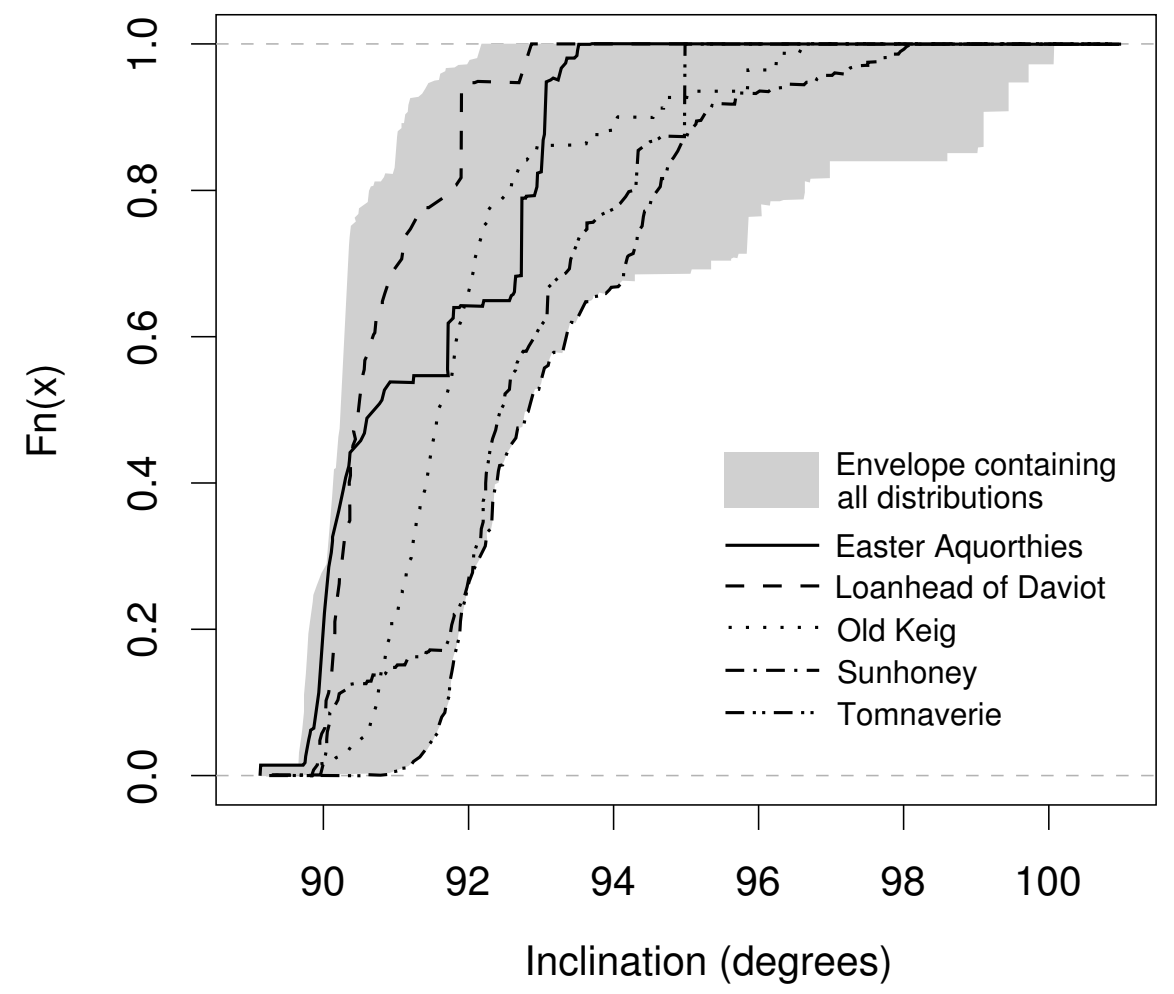


Figure 5: Azimuthal variation in horizon properties at Easter Aquorthies and Loanhead of Daviot
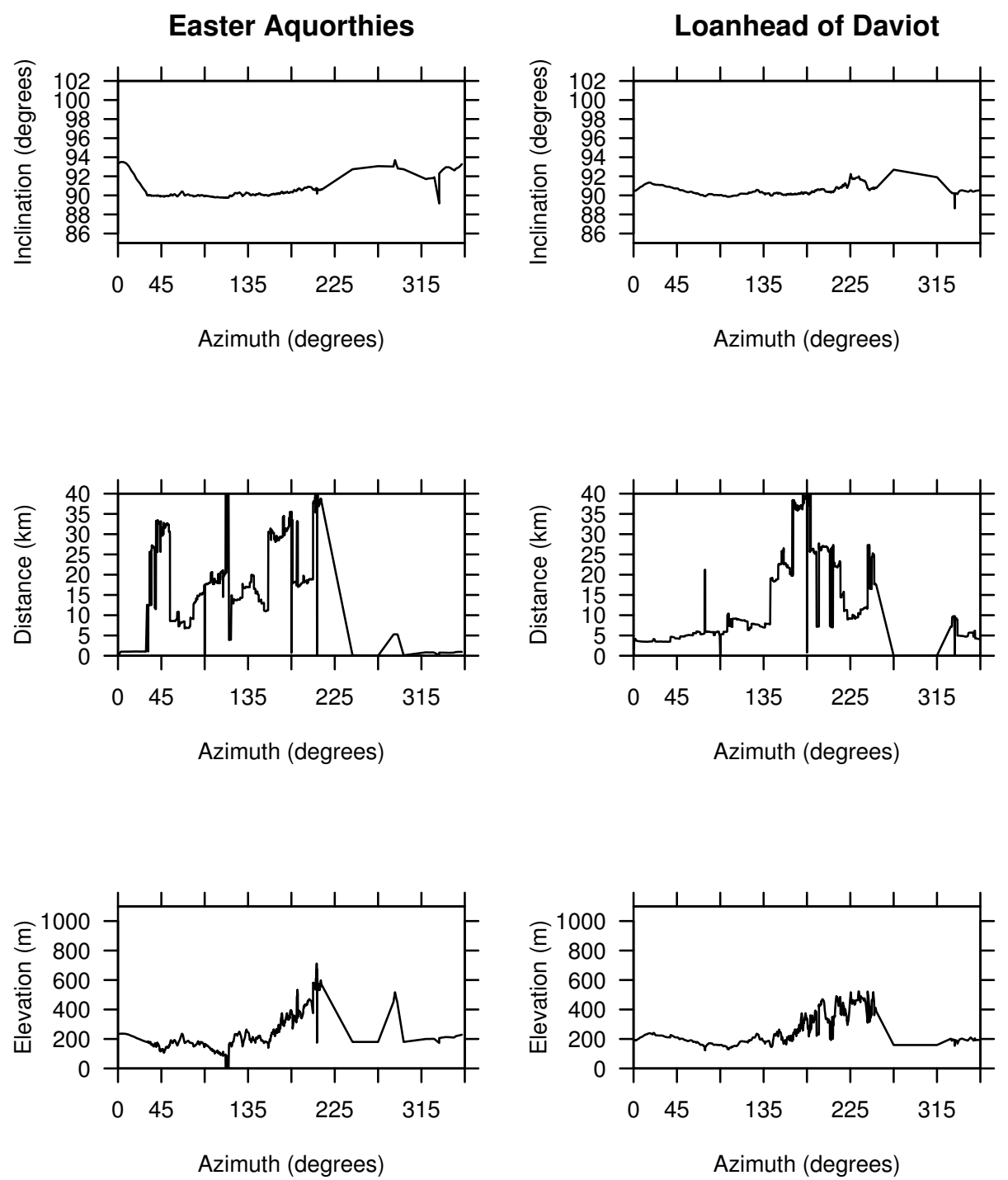
Figure 6: Azimuthal variation in horizon properties at Old Keig and Sunhoney
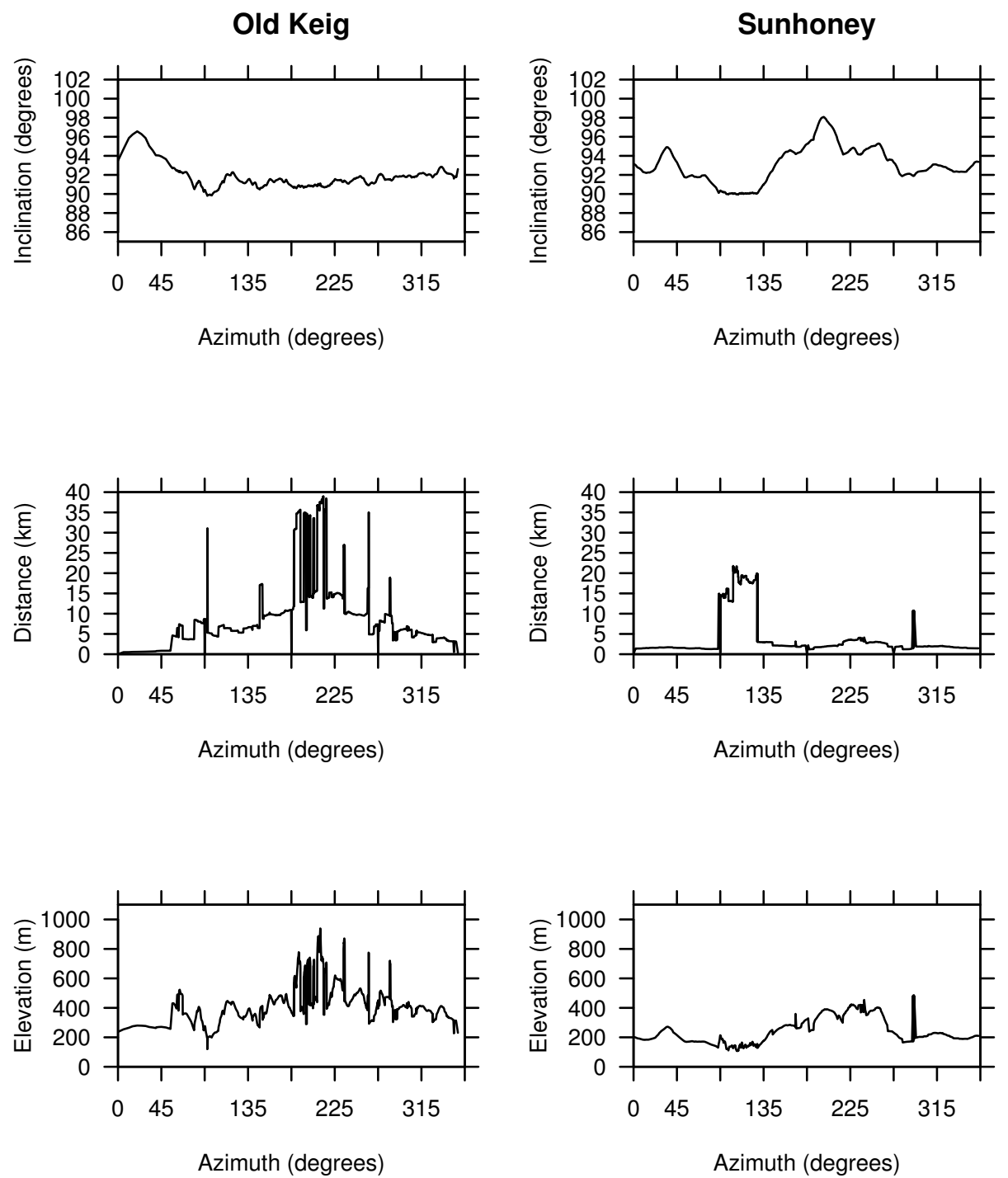
Figure 7: Azimuthal variation in horizon properties at Tomnaverie
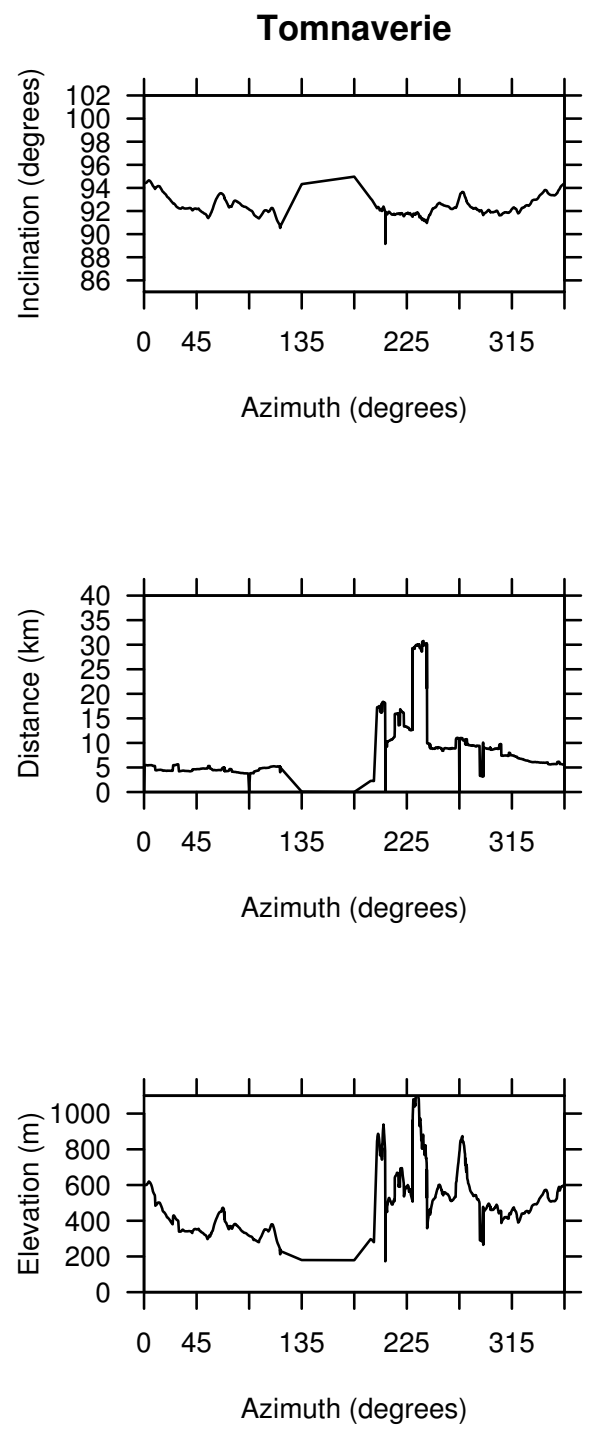